\title{
DOCUMENTATION OF ADMINISTRATIVE ACTIVITIES BY THE POLICE OF UKRAINE
}

\section{Predmestnikov O. G.}

\section{INTRODUCTION}

The work is supposed to consider the documentation of administrative offenses by the police, namely the bringing of protocols on administrative offenses, decisions in the case of an administrative offense and the rules by which they are drawn up.

\section{Documentation of administrative offences by the National police of Ukraine}

According to item 1 of section II of the Instruction on registration of materials on administrative offenses in police bodies approved by the order of the Ministry of internal Affairs of 06.11.2015 No. 1376 protocols on: administrative offense; administrative detention; withdrawal of things and documents; inspection of things and personal inspection, and also receiving explanations from persons who are brought to administrative responsibility, victims, witnesses are carried out by authorized officials of police bodies ${ }^{1}$.

About Commission of an administrative offense, the Protocol is made.

Authorized officials of the police shall carry out preparation of protocols on administrative offenses, protocols on administrative detention, and protocols on seizure of things and documents, protocols on inspection of things and personal inspection, as well as obtaining explanations from persons brought to administrative responsibility, victims, witnesses.

On Affairs about administrative offences, the consideration of which is within the competence of the police authorities referred to in article 222 of the CAO, protocols in accordance with article 255 of the CAO be authorized officials of these bodies.

Protocols on administrative offences shall not be drawn up in cases provided for in article 258 of the CAO.

If, during the judgement in the case of an administrative offence the person contesting the violation and the administrative penalties that it imposed, the authorized official person of the police authority is obliged to draw up a Protocol on administrative offense under article 256 of the CAO,

${ }^{1}$ Krasnitskaya A. Problems of formation of definition of legal technique in post-Soviet times. Scientific Bulletin of KNUVD. 2010. 
except bring the person to administrative responsibility for committing an administrative offense under article 185-3, Art.

In case of Commission of an administrative offense by persons who have reached the age from which administrative responsibility comes, the authorized officials of police bodies make the Protocol on an administrative offense $^{2}$.

At insignificance of the made administrative offense the body (official) of police authorized (and) to consider business, can release the violator from administrative responsibility and be limited to the oral remark.

Administrative Protocol is a procedural document of different content and purpose, with the help of which an official or a representative of a public organization records the Commission of an administrative offense.

The Protocol on administrative offense is made on the special form which is made by the typographical method.

The form of the Protocol on an administrative offense is a sheet of paper with a size of $210 \times 297 \mathrm{~mm}(+-0.5 \mathrm{~mm})$ weighing $80 \mathrm{~g} / \mathrm{sq}$. $\mathrm{m}$ and consists of a Protocol and a copy. The Protocol and the copy are printed on self-copying paper from the front side in three colors by means of offset printing. On the form of the Protocol on an administrative offense the perforation line at distance of $20 \mathrm{~mm}$ from the left edge is put. The Protocol series consists of a letterhead, a number, and a six-digit numeric index, performed by highresolution printing ${ }^{3}$.

The text part is printed in green paint. The Protocol form itself is protected by small security elements:

1) micro shrift in the positive image on the Protocol and a copy of the form;

2) an irregular computer background grid for the Protocol, which is executed in blue and for the copy in yellow.

The Protocol indicates the name of the manufacturer, number, year and quarter of the order is printed on the front side of the Protocol and a copy.

All protocols on administrative offenses are completed with blocks of 20 copies. After the last copy, the block is completed with a clean cardboard page.

The Protocol on administrative offense is filled in ink of black or blue color, legible handwriting, in the state language.

\footnotetext{
${ }^{2}$ Tertyshnyk V. Criminal procedure law of Ukraine: textbook. The 4th form., additional and pererab. K.: A. S. K. publishing House, 2017. 1120 p.

Krasnitskaya A. Law enforcement errors in the texts of procedural acts of criminal proceedings. The court of appeal. 2016. No. 1. P. 28-33.
} 
The Protocol on an administrative offense is formed in two copies, one of which is handed over to the person brought to administrative responsibility under the receipt. In drawing up the Protocol on administrative offense the person brought to administrative responsibility, shall be explained his rights under articles 55, 56, 59, 63 of the Constitution of Ukraine, article 268 of the administrative code, it is reported that the case of an administrative offense will be dealt with in the terms defined by the article 277 of the CAO, which is the mark and signature of the person, brought to administrative responsibility.

The person brought to administrative responsibility has the right to submit explanations and remarks concerning the contents of the Protocol on an administrative offense and explanations on the essence of an administrative offense which are attached to the Protocol on an administrative offense, and also to state motives of the refusal to sign it. If the person against whom the Protocol on an administrative offense is drawn up does not speak the Ukrainian language, the Protocol on an administrative offense is drawn up with the participation of an interpreter ${ }^{4}$.

In the Protocol on administrative violation shall contain: date and place of its execution, position, surname, name, patronymic of the person who made the report; information about the person, brought to administrative responsibility (in the case of her identification); place, time of committing and the essence of the administrative offence; the normative act providing responsibility for the offense; the names, addresses of witnesses and victims, if any; an explanation of the person, brought to administrative responsibility; any other information needed for resolution of the case. If the offense caused material damage, this is also indicated in the Protocol. Thus:

- in the column "place of drawing up the Protocol" the settlement or geographical point is specified;

- in the column "position, name of police body, rank, surname, name, patronymic of the person who made the Protocol" the surname, name, patronymic of the official who made the Protocol is specified (completely, without abbreviations);

- in the column "made this Protocol that the citizen" it is necessary to specify a surname, a name and a patronymic of the person brought to administrative responsibility (completely, without reductions);

- in the column "Title of document, series, number, whom and when issued" reflects the identity document (series, passport number, date of issue and name of the authority that issued it, or number of other identity document, commits an offence (service or pension certificate, student ID,

\footnotetext{
${ }^{4}$ Kashanina T. Legal technique: student. Moscow: Eksmo, 2011.
} 
etc.), date of issue and name of the body (institution, enterprise, organization) which issued it (and));

- in the column "or was brought (Las) to administrative responsibility" should contain information on attraction of the person to administrative responsibility within a year (in the presence of);

- in the column "date, time, place of Commission and the essence of an administrative offense" is necessary to explain the essence of the administrative offense (must exactly match the signs of an administrative offense specified in article of the administrative code, according to which the Protocol);

- in the column "to the Protocol is attached" explanations of the person who has committed an administrative offense are specified, are stated on a separate sheet, reports of officials of police bodies, certificates, acts, etc. (in case of drawing up).

The authorized official who made it signs the Protocol on an administrative offense, and the person brought to administrative responsibility. In the presence of witnesses and victims the Protocol on an administrative offense can be signed also by these persons. In case of refusal of the person brought to administrative responsibility to sign the Protocol on an administrative offense in it record about it becomes ${ }^{5}$.

To the person concerning whom the Protocol on an administrative offense is made, it is offered to provide on the merits of the committed administrative offense the written explanation which is signed by the specified person. The explanation can be attached to the Protocol on an administrative offense separately about what record in it becomes. Other materials on administrative offense (explanations of victims, witnesses, expert opinion, physical evidence, Protocol on seizure of things and documents, reports of officials, as well as other documents and materials containing information about the offense) are also attached to the Protocol on administrative offense.

In any case, it is not allowed to cross out or correct the information that is entered in the Protocol on an administrative offense, as well as to make additional entries after the Protocol on an administrative offense is signed by the person in respect of whom it is drawn up.

The Protocol on an administrative offense, in case of its registration, is made in two copies, one of which under the receipt is handed over to the person brought to administrative responsibility.

\footnotetext{
${ }^{5}$ Samples of civil legal documents: scientific and practical guide / ed. V. A. Kuznetsov. Kiev: Istina, 2017. 712 p.
} 
If the offense is committed by several persons, the Protocol on an administrative offense is made concerning each person separately.

The Protocol on an administrative offense and materials on the committed administrative offense are sent to the body authorized to consider cases on administrative offenses ${ }^{6}$.

In case of Commission of an administrative offense by the minor at the age from fourteen to sixteen years the Protocol on an administrative offense as a General rule is made concerning one of parents of the minor or the person who replaces them, according to part three of article $184 \mathrm{CAO}$. The exception takes place on condition of Commission by the minor person at the age from sixteen to eighteen years of the administrative offenses provided by articles 44, 51, 121-127, h. 1-3 of Art. 130, Art. 139, h. 2 of Art. 156, art. 173, 174, 185, 190-195 CAO, the Protocol on an administrative offense is made concerning this person.

The Protocol on administrative detention of the person who has committed an administrative offense is made on the special form made by the printing method. The technical requirements for the form of the Protocol on administrative detention are identical to the requirements for the Protocol on administrative offense. Completed copies in blocks of 30 pieces.

The Protocol on administrative detention shall specify: the date and place of its preparation; the position, surname, name and patronymic of the person who drew up the Protocol; information about the identity of the detainee; time and motives of detention. Thus:

- in the column "position, name of the police body, rank, P. I. the person who made the Protocol" the surname, a name, a patronymic of the official who made the Protocol (completely, without abbreviations is specified);

- in the column "grounds for detention: suppression of an administrative offence, Protocol of administrative offence for consideration of the case" indicates the termination of administrative offences or other measures of exposure;

- the Protocol on administrative violation in case of failure of drafting him in the Commission of an offense if the preparation of a Protocol is mandatory;

- ensure timely and lawful consideration of the case.

At drawing up the Protocol on administrative detention the official performing it, explains to the person who has committed an administrative offense, its rights provided by articles 55, 56, 59, 63 of the Constitution of

\footnotetext{
${ }^{6}$ Dutko A. General characteristics of the legal and technical norm-setting. Herald Of Lions. UN-Tu. 2000. Vol. 35. P. 48-51.
} 
Ukraine and article $268 \mathrm{CAO}$. According to the Law of Ukraine "On free legal assistance" and paragraphs 2, 10 the procedures for informing of the centers providing free secondary legal assistance about cases of detention of persons, approved by the decree of the Cabinet of Ministers of Ukraine of 28 December 2011 No. 1363, during a Protocol on administrative detention of a person who committed an administrative offense, shall be explained his right to free secondary legal aid $^{7}$.

Gratuitous secondary legal aid is a type of state guarantee, which consists in creating equal opportunities for persons to access justice. It includes the following types of legal services:

1) protection;

2) representation of the interests of persons entitled to free secondary legal assistance in courts, other state bodies, local self-government bodies, before other persons;

3) preparation of procedural documents.

All details of the Protocol on administrative detention are filled in legible handwriting. It is not allowed to cross out or correct the information that is entered in the Protocol on administrative detention, as well as to make additional entries after the Protocol on administrative detention is signed by the person against whom it is drawn up.

The Protocol shall be signed by the official who drafted it and the detainee. In case of refusal of the detainee from signing of the Protocol in it record about it becomes. In accordance with the second part of article 261 of the CAO, the place of stay of a person detained for committing an administrative offense is immediately reported to his relatives, and at her request to the owner of the relevant enterprise, institution, organization or body authorized by him. About it in the Protocol on administrative detention the corresponding record is made, the number, month, year and time to whom it is reported and in what way are specified.

In case of impossibility to inform relatives and in case of refusal of the detained person to provide information for their notification about it the corresponding record is made by the detained person and the official who made the Protocol on administrative detention, with indication of valid reasons.

The detention of a minor must be reported to his parents or persons who replace them. In the Protocol on administrative detention the time, date of the message, whom it is reported and how are specified.

\footnotetext{
${ }^{7}$ Michurin E. Technique of drafting contracts: scientific and practical guide. A series of "Practice and law". Kharkov : Urxvt, 2017. 536 p.
} 
Before being placed in the detention room duty of the police authority in the office where delivered to the person who committed an administrative offence under article 264 of the CAO by the duly authorized person of the same sex with the person who delivered, in presence of two witnesses (witnesses) of the same sex is a personal inspection and inspection of items delivered to the person ${ }^{8}$.

In urgent cases these things, objects can be subjected to inspection with the participation of two witnesses (witnesses) in the absence of the owner (owner).

About carrying out personal inspection and inspection of things the Protocol in which are specified is made:

- date, time, place of its compilation;

- the official of the police body who composed it (in full, without abbreviations);

- surnames, names and patronymics, places of residence of two witnesses (fully, without abbreviations);

- surname, name, and patronymic (in full, without abbreviations), the place of residence of the person who is examined and at whom examine things, values, documents which are the tool or object of an offense;

- signs of individual things, valuables and documents;

- places and circumstances of detection.

The Protocol of personal inspection and inspection of things is signed by the person who was subjected to the review and at whom examined things understood and the official of body of police who made it.

About personal inspection and inspection of things of the person who has committed an administrative offense, the corresponding record in the Protocol on an administrative offense or in the Protocol on administrative detention where are specified is made:

- surnames, names and patronymics, places of residence of two witnesses;

- a list of things being inspected, and items of clothing that are on her face at the time of her detention;

- information on the presence or absence of bodily injuries of the detainee. If injuries are found, it should be noted on which parts of the body they are and their nature (bruises, scratches, cut wounds, etc.).

If the detainee needs medical assistance, the official of the police body calls an ambulance. In the Protocol on an administrative offense time of rendering medical care, number of crew of emergency medical care, a

\footnotetext{
${ }^{8}$ Rona A. Collection of claims. practical guide. Kyiv: CST, 2017. 204 p.
} 
surname and initials of the doctor to whom establishments of health care of the detainee is directed are specified.

At receipt from the detainee during carrying out personal inspection, inspection of things of complaints or remarks in the Protocol on administrative detention the corresponding record with indication of their essence becomes.

When the detained person is released from the place of his stay, the Protocol on administrative detention is noted, in particular, in the column "complaints, comments to the actions of police officials do not have / have" and the presence or absence of comments and complaints about the actions of police officials, stating their essence.

According to article 265 of the CAO, things and documents that are the instrument or the direct object of an offence, identified during detention, personal search or police officials seize inspection of things. In the Protocol on an administrative offense or in the Protocol on administrative detention the corresponding record about what things, objects, documents which are the tool or direct object of an offense are withdrawn from the detainee is made, their individual signs, numbers, a place and circumstances of their detection are specified.

A conclusion is a document that records the thought, conclusion of a body (official), Commission or specialists on any issue, document or other materials. The opinion may be sent to a higher authority or official with subsequent approval.

The main details of the conclusion: the name of the type of document (Conclusion); title; text that contains an assessment of the work, comments and suggestions; special title, surname, initials of the originator; signatures; date.

The text of the conclusion consists of two parts. The first sets out the essence of the issue, which is considered, the facts and results of the audit, the second-formulated conclusions and proposals for the work carried out.

An explanation is a document that sets out events or facts that are relevant in the case in question.

Explanation you must specify the position, special title, surname and initials of the person against whom the explanation is made; the name of the document (Explanations); the date, place of writing; text; surname, initials and signature of the person who gave the explanation; the signatures of officials selected explanations, as well as persons who were present when the document (if required by law). Explanation, as a rule, is written by the person or the official with own hand about what record in explanation becomes.

All documents, wherever and by whom they are concluded, have legal, technical, logical and linguistic requirements. 
Legal requirement. The document is issued by an authorized body or person in accordance with its competence. The document should not contradict the current legislation and directives of the governing bodies, should be reliable and meet the tasks of the specific management, i.e. be based on facts and contain concrete and real proposals or instructions. The document must be in the prescribed form. It should be flawlessly edited and decorated. It does not allow legal and grammatical errors. The texts of business documents use the official business style.

Specifications. For the conclusion of any document, there is an appropriate white paper size. The generally recognized A4 format, the text of which is printed in one and a half line intervals, on A5 format forms-in one interval. Certain requirements and rules for page design and numbering have been developed and are in force in office work ${ }^{9}$.

At registration of documents on two and more pages, since the second, they should be numbered. The number is put down in the middle of the upper Bank of the page in Arabic numbers. Dots and dashes before and after numbers are not put. The page number is printed in the interval of 10-15 mm. from the upper shore. Business documents are typed with 14 pins in the Word editor (Times New Roman font), upper and lower indents $-2 \mathrm{~cm}$, left $-3 \mathrm{~cm}$, right $-1 \mathrm{~cm}$.

If the document is also drawn up on the reverse side (the shelf life of such a document should be no more than three years), the left and right banks on the back are respectively reversed.

The name of the document should be printed in 16 pins, large letters, bold and placed in the center of the line of the form.

The date in the document is written in Arabic numerals in one line in the sequence: number, month, year: 12.09.2006. If the serial number of the month or number consists of a single-digit number, then 0: 02.09.2006 is put before it.

Legal acts and financial documents use the word-digital method of registration of the date - September 15, 2006.

Logical requirements are characterized by the use of means of logical evaluation of the material for the coherence of the individual parts, indicating the order of implementation (first of all, at the same time, in particular, consequently); taking into account such elements as the relevance of the facts and their timeliness; the sequence of the text and its parts.

The logical sequence of presentation is especially expressive in those types of business documents, where subjective elements are completely

9 Krasnitskaya A. Procedural acts of criminal proceedings: legal technique, ways of improvement: abstract. dis. for the Sciences. the degree candidate. Yuri. sciences'. Kiev, 2008. 
excluded: manifestations of irritation, discontent, bringing a personal attitude to the case or the person in the text of the document.

Signs of logical sequence: close logical connection of all components of the document, clearly identified cause-and-effect relationships between the reported facts. The logical sequence of the business document can also be realized in other types of relationships: this opposition (it is most often expressed by words but, however); identification and logical assertion of the priority (now, later); target (to this end, for, so), effectiveness (therefore, thus, as a result, in General); this specification anywhere in the document (for example, in particular, for example).

The logical sequence of presentation is also achieved by clearly dividing the text of the document into separate paragraphs. External manifestations of this division are numbering, letters, paragraphs.

Linguistic requirements. The text of the business document is its basis, it must be competent. The written form of speech requires clear syntactic constructions, strict observance of stylistic norms and rules of grammar. In particular, language literacy is the observance of the norms of spelling, punctuation and grammar. All terms, special concepts, constructions formed under the influence of the peculiarities of professional thinking should correspond to the modern level of legal knowledge, be used only when they are really necessary.

The text of the document should be clear. The language of official documents is abstracted from the individual speech characteristics of people, which requires a certain formalization of the language, the use of standard terms, established language structures with established rules of their interpretation. (The choice of words and terms, sustainable speed (based on the above, in accordance with the requirements of the decree, pursuant to article of the criminal code of Ukraine is brought (filed) charges, etc.), sentence structure, form of presentation of document (order, offer, require, listened, acted, decided, please, send, sent for review and the like).

All of the above requirements for the preparation of documents constitute a common culture of speech of the individual, because the high culture of human speech determines perfect command of the literary language, the ability to correctly apply its norms in the process of speech activity ${ }^{10}$.

The concept of high culture of office work and culture of language of documents is realized in such specific requirements:

${ }^{10}$ Tertyshnyk V. Criminal procedure law of Ukraine: textbook. The 4th form., additional and pererab. K.: A. S. K. publishing House, 2017. 1120 p. 
- the document is issued by an authorized body or person in accordance with the competence;

- the document cannot contradict the current legislation, Directive instructions of governing bodies;

- the document should be reliable and consistent with the objectives of the specific management, that is, based on facts and contain specific real proposals or instructions;

- the document should be in the prescribed form;

- the document must be flawlessly edited and decorated.

The appearance of the document is an indisputable evidence of the management style, discipline and personal culture of employees.

\section{Administrative-procedural documents adopted during the proceedings in cases of administrative offenses}

An administrative decision is a procedural document that is drawn up after consideration of a case of an administrative offense by a body or official. In the resolution state and justify the decision made during administrative proceedings.

The decision of the Executive body of the village, village Council in the case of an administrative offense is taken in the form of a decision.

The form of the resolution on the case of an administrative offense is filled in legible handwriting. It is not allowed to cross out or correct the information that is entered in the decision, as well as making additional entries after the decision is signed by the person against whom it is made. In case of violations in the design of such a decision, its completed form is considered spoiled ${ }^{11}$.

When making a decision in the case of an administrative offense, it shall specify, in particular:

- in the column "position, name of the police body, rank, surname, name and patronymic of the person who made the decision" - surname, name, patronymic of the official of the police body who made the decision, and the police body (in full, without abbreviations);

- in the column "established" - number, month, year, time and place of Commission of an administrative offense, and also circumstances and an offense essence established at consideration of materials of administrative case;

- in the column "considering that citizen" - the surname and initials of the offender;

\footnotetext{
${ }^{11}$ Rona A. Collection of claims. practical guide. Kyiv: CST, 2017. 204 p.
} 
- in the column "decided" - the authorized official of the police body, taking into account and indicating the circumstances mitigating (article 34 of the administrative code) or aggravating (article 35 of the administrative Code) responsibility for an administrative offense, notes the decision taken in the case.

In the case of an administrative offence, the official of the police body that is considering it, in accordance with article 284 of the CAO, shall make one of these decisions:

1) on the imposition of an administrative penalty;

2) on closing the case.

The decision of the case on administrative offence is signed by the official who considered the case, and resolution of collegial body - the person presiding at the meeting and the Secretary of this body.

In cases stipulated by the legislation of Ukraine, the appropriate record on the Protocol on an administrative offense is made or the resolution is made out in another established way (article 283 of the Code of administrative offenses of Ukraine).

In the case of an administrative offense, the body (official) makes one of these decisions:

a) on the imposition of an administrative penalty;

b) about application of the measures of influence provided by Art. 24-1 of the Code about administrative offenses of Ukraine;

c) on closing the case.

After considering the case on administrative offence, depending on the results of its review authority which considered the materials of the administrative case and took out the decree, decides whether the seized documents or things, on their forfeiture in the prescribed manner, refund to the owner or destroyed, as recorded in the resolution. The resolution is signed by the official who made it.

The decision is announced immediately after the end of the consideration of the administrative case.

A copy of the decision in the case of an administrative offense within three days is handed over or sent to the person in respect of whom this decision is made. A copy of the decision on the case of an administrative offense is handed to the person brought to administrative responsibility, personally under the signature. In the decision on the case of an administrative offense the date of its delivery is specified and the signature of the offender is put. If a copy of the decision in the case of an 
administrative offense is sent by mail, the corresponding mark is made in the case, to which the spine of the mail notification of its receipt is attached ${ }^{12}$.

A copy of the decision on the case of an administrative offense in the same period is handed over or sent to the victim at his request (it indicates the date of its delivery and the signature of the person who received it).

According to article 293 of the CAO, an official of the police body authorized to consider cases of administrative offenses, when considering a complaint against a decision in an administrative offense case, checks the legality and validity of its issuance and takes one of the following decisions:

1) leaves the resolution of administrative proceedings without change, and the complaint and makes a decision on leaving the decision in the case of an administrative offense without change, but complaint or the Prosecutor without satisfaction;

2) repeals the decision on the case of an administrative offense and sends the case for consideration and makes a decision to cancel the decision on the case of an administrative offense and transfer the case to a new hearing;

3) cancel the ruling in the administrative proceedings and closes the case and makes a decision about cancellation of the resolution on case about administrative offense and dismiss the case;

4) changes the measure of recovery within the limits provided by the regulatory act on responsibility for an administrative offense, but without strengthening the recovery, and decide to change the measure of recovery.

A copy of the decision on the complaint against the decision within three days is sent to the person against whom it is made, in the same period a copy of the decision is sent to the victim at his request.

\section{Features of office work in cases of administrative offenses}

It should be noted that the proceedings in cases of administrative offenses has a number of specific features. So, forms of protocols on administrative offenses and protocols on administrative detention are documents of strict accounting and are printed with the indication of a series and number.

Quantitative records of the receipt, issuance and use of forms are kept in an electronic journal using automated information retrieval systems by the police officer, who is entrusted with the relevant duties.

${ }^{12}$ Krasnitskaya A. Legal documents: technique of drawing up, registration and editing: manual / A. Krasnitskaya. - 2nd view., please. Kyiv: parliamentary Publishing house, 2006. $537 \mathrm{p}$. 
On identification of the spoiled forms (mechanical damages, printing marriage) it is reported to the head of the corresponding division.

Spoiled, returned or having typographical defects, forms of protocols, resolutions and temporary permits are destroyed and written off according to the act of monthly write-off of blank products.

On the basis of the act of monthly write-off of blank products, data on their deregistration are entered in the electronic journal.

In case of detection of loss of forms of protocols, resolutions and temporary permissions the management of the corresponding division carries out office checks.

Administrative materials issued by the police, within a day are sent to the administrative practice units for their further registration and processing.

The person exercising control over the use of forms on an administrative offense and the resolution on an administrative offense, at the same time checks the legality of registration of administrative materials.

Temporarily seized documents be returned when there are grounds for a refund (court order, certificate of civil servants of the criminal-Executive inspection, the act-marked officials about elimination of the revealed violations and documents confirming the payment of the fine) by the authorized persons of the respective units of the patrol police in accordance with applicable law.

Documents that are the basis for the return of temporarily seized driver's licenses are entered into the automated information retrieval system by the authorized person of the patrol police unit.

Cases of violations of rules, norms and standards in the field of road safety are subject to storage for three years. Materials on violation of traffic rules, recorded with the help of photo, video or filming are stored in the unit in electronic form for three months from the date of fixing the violation.

Filling in the written form of protocols on administrative offenses, resolutions on bringing to administrative responsibility, temporary permissions is carried out in ink (paste) of black or blue color. Entries are made in legible handwriting, and the surname, name, patronymic of the person, brought to administrative responsibility, his place of residence (stay), place of work and position, special title, surname, name, patronymic of the police written in block letters.

The organization of control over the procedure for the implementation of proceedings in cases of administrative offenses in the police is carried out by their direct heads.

Control over compliance with the requirements for keeping a log of issuance of forms of protocols on administrative offenses, forms of resolutions on cases of administrative offenses and forms of protocols on 
administrative detention and their use is assigned to one of the Deputy heads of the police body, which is determined responsible in accordance with the order of the head of this body.

Direct control over observance by authorized officials of the legislation during implementation of proceedings on cases of administrative offenses is assigned to heads of structural divisions of body of police.

\section{CONCLUSIONS}

Authorized officials of the police shall carry out preparation of protocols on administrative offenses, protocols on administrative detention, and protocols on seizure of things and documents, protocols on inspection of things and personal inspection, as well as obtaining explanations from persons brought to administrative responsibility, victims, witnesses.

Administrative Protocol is a procedural document of different content and purpose, with the help of which an official or a representative of a public organization records the Commission of an administrative offense.

The Protocol on administrative offense is made on the special form which is made by the typographical method.

An administrative decision is a procedural document that is drawn up after consideration of a case of an administrative offense by a body or official. In the resolution state and justify the decision made during administrative proceedings.

Control over compliance with the requirements for keeping a $\log$ of issuance of forms of protocols on administrative offenses, forms of resolutions on cases of administrative offenses and forms of protocols on administrative detention and their use is assigned to one of the Deputy heads of the police body, which is determined responsible in accordance with the order of the head of this body.

\section{SUMMARY}

Hence, the administrative documents adopted in the process of performing activity on the basis and to execute laws of Ukraine unilateral power guidelines aimed at establishing, changing or terminating specific legal relations or such that are binding on subordinate bodies and officers of the internal Affairs rules (norms) with the purpose of the organization and practical realization of the rights of citizens and public order. They reflect the internal activities of the internal Affairs bodies on the organization, practical implementation of the protection of public order, public security.

Administrative acts are adopted in each individual case of application of administrative penalties to offenders. With their help, the sub-divisions of 
the internal Affairs bodies organize and send to the legal channel the behavior of persons who do not obey the law.

During the administrative review, in accordance with the current legislation, various documents are drawn up, which are divided into basic (mandatory) and auxiliary (optional).

The main (mandatory) documents include protocols (on administrative offense, on administrative detention of a person) and resolutions on administrative offenses. In these documents, a significant part of the work on the protection of public order is legally reflected. The procedure of preparation and registration of documents made by manufacture on Affairs about administrative offences are defined in the legislation of Ukraine on administrative offences, the Code of Ukraine about administrative offenses and the Instruction on registration of materials about administrative offenses, approved by Order of MIA of Ukraine № 185 dated 22.02.2001 of the year.

To auxiliary (optional) administrative documents which are made in each case separately concern: the statement, the report, the extract, the conclusion, the office letter, the reference and so forth. These types of documents contribute to the adoption of correct decisions by a collective body, official, public organization or public self-government body; ensure the rights of participants in the administrative process and contribute to the performance of their duties.

\section{REFERENCES}

1. Samples of civil legal documents: scientific and practical guide / ed. V. A. Kuznetsov. Kiev: Istina, 2017. 712 p.

2. Korzh A. Legal documentation. Kiev, 2011.

3. Krasnitskaya A. Procedural acts of criminal proceedings: legal technique, ways of improvement: abstract. dis. for the Sciences. the degree candidate. Yuri. sciences'. Kiev, 2008.

4. Krasnitskaya A. Improvement of the language of procedural acts of criminal proceedings. Ukrainian language in law: state, problems, prospects: collection of materials of Sciences. - pract. Conf. Kiev, 2016. P. 79-82.

5. Krasnitskaya A. Legal technique of procedural acts of criminal proceedings. Scientific Bulletin NADU. No. 2. 2003. P. 120-128.

6. Krasnitskaya A. Legal documents: technique of drawing up, registration and editing: manual / A. Krasnitskaya. - 2nd view., please. Kyiv: parliamentary Publishing house, 2006. 537 p.

7. Michurin E. Technique of drafting contracts: scientific and practical guide. A series of "Practice and law". Kharkov: Urxvt, 2017. 536 p.

8. Dutko A. General characteristics of the legal and technical normsetting. Herald of Lions. UN-Tu. 2000. Vol. 35. P. 48-51. 
9. Kashanina T. Legal technique: student. Moscow: Eksmo, 2011.

10. Krasnitskaya A. Rules, requirements of legal technique concerning the procedural acts of criminal proceedings. Jurisprudence: theory and practice. 2009. No. 1. P. 7-13.

11. Krasnitskaya A. Law enforcement errors in the texts of procedural acts of criminal proceedings. The court of appeal. 2016. No. 1. P. 28-33.

12. Krasnitskaya A. Problems of formation of definition of legal technique in post-Soviet times. Scientific Bulletin of KNUVD. 2010.

13. Rozhnova V. Workshop on the preparation of criminal procedural documents (pre-trial proceedings): studies. - pract. possib. with method. recom. Kiev: View. Palivoda A.V., 2009. 308 s.

14. Rona A. Collection of claims. practical guide. Kyiv: CST, 2017. $204 \mathrm{p}$.

15. Tertyshnyk V. Criminal procedure law of Ukraine: textbook. The 4th form., additional and pererab. K.: A. S. K. publishing House, 2017. 1120 p.

Information about the author: Predmestnikov O. G., Doctor of Law, Professor, First Deputy Head of the Main Territorial Department of Justice in the Kherson Region 42/14, Potiomkinska str., Kherson, 73040, Ukraine 